\title{
JcTI-I: a novel trypsin inhibitor from Jatropha curcas seed cake with potential for bacterial infection treatment
}

\section{Helen P. S. Costa ${ }^{1}$, Jose T. A. Oliveira ${ }^{1}$, Daniele O. B. Sousa ${ }^{1}$, Janne K. S. Morais ${ }^{1}$, Frederico B. Moreno ${ }^{2}$, Ana Cristina O. Monteiro-Moreira ${ }^{2}$, Ricardo A. Viegas ${ }^{3}$ and Ilka M. Vasconcelos ${ }^{1}{ }^{*}$}

' Laboratory of Plant Toxins, Department of Biochemistry and Molecular Biology, Federal University of Ceara, Fortaleza, Brazil

${ }^{2}$ School of Pharmacy, University of Fortaleza, Fortaleza, Brazil

${ }^{3}$ Department of Forestry Engineering, Federal University of Campina Grande, Patos, Brazil

\section{Edited by:}

Octavio Luiz Franco, Universidade Catolica de Brasilia, Brazil

\section{Reviewed by:}

Noton Kumar Dutta, Johns Hopkins University, USA

Maria Ligia Macedo, Universidade Federal de Mato Grosso do Sul, Brazil Norelle Daly, James Cook University, Australia

\section{${ }^{*}$ Correspondence:}

Ilka M. Vasconcelos, Laboratory of Plant Toxins, Department of

Biochemistry and Molecular Biology, Federal University of Ceara, Fortaleza, CE 60451-970, Brazil

e-mail: imvasco@ufc.br

\begin{abstract}
Jatropha curcas seed cake is a low-value by-product resulting from biodiesel production. The seed cake is highly toxic, but it has great potential for biotechnology applications as it is a repository of biomolecules that could be important in agriculture, medicine, and industry. To explore this potential, a novel trypsin inhibitor called JcTI-I was purified by fractionation of the crude extract with trichloroacetic acid $(2.5 \%, \mathrm{v} / \mathrm{v})$ followed by affinity chromatography (Trypsin-Sepharose 4B) and molecular exclusion (Sephacryl S-200). Non-reducing sodium dodecyl sulfate-polyacrylamide gel electrophoresis and gel filtration showed that JcTI-I has approximately $20.0 \mathrm{kDa}$. Mass spectrometry analysis revealed that the intact molecular mass of $\mathrm{JcTl}-\mathrm{I}$ is $10.252 \mathrm{kDa}$. Moreover, $\mathrm{JcTl}-\mathrm{I}$ is a glycoprotein with $6.4 \%(\mathrm{~m} / \mathrm{m})$ carbohydrates, $\mathrm{p} /$ of $6.6, \mathrm{~N}$-terminal sequence similarity around $60 \%$ to plant albumins and high stability to heat, $\mathrm{pH}$, and salinity. $\mathrm{JcTI}-\mathrm{I}$ presented antibacterial activity against the human pathogenic bacteria Salmonella enterica subspecies enterica serovar choleraesuis and Staphylococcus aureus, with minimum inhibitory concentration less than $5 \mu \mathrm{g} / \mathrm{mL}$. Furthermore, JcTI-I did have inhibitory activity against the serine proteases from the tested bacteria. Otherwise, no hemolytic activity of human erythrocytes and signs of acute toxicity to mice were observed for JcTI-I. The results demonstrate the benefits of $J$. curcas seed cake as a source of trypsin inhibitor with potential for biotechnological application as a new antimicrobial agent against human pathogenic bacteria.
\end{abstract}

Keywords: Jatropha curcas, seed cake, serine proteinase inhibitor, trypsin inhibitor, bacterial infections, antimicrobial agent

\section{INTRODUCTION}

Hospital-acquired infection is the major cause of death in critically ill patients, both in developing and developed countries (Ramsamy etal., 2013). These infections are a challenge to patient safety because the causal agents have developed antibioticresistance, thus limiting treatment options (Mulvey and Simor, 2009; Becker etal., 2012). For example, both the methicillinresistant Staphylococcus aureus (MRSA) and multidrug-resistant Salmonella enterica are the principal multidrug resistant bacterial pathogens that cause serious community and hospital-acquired infections, responsible for high annual health care costs and psychological stress associated with social stigma (Cosgrove etal., 2003; Brydon et al., 2009; Broughton et al., 2010). Therefore effective new therapeutic agents with novel mechanisms of action for treatment of infections caused by multidrug resistant bacteria are urgently needed (Hughes et al., 2012). In this context, as plants have numerous therapeutic compounds they constitute natural targets from which new antibacterial drugs with high efficacy and less toxicity can be developed to treat infectious diseases (Ngo et al., 2013). Indeed, biologically active compounds from plant resources have been extracted from different species (Savoia, 2012).

Jatropha curcas, also known as physic nut, is a shrub belonging to the Euphorbiaceae family. This species is highly adaptable to adverse conditions and is resistant to many pests and pathogens (Debnath and Bisen, 2008; Sabandar et al., 2013). In addition, J. curcas seeds constitute an oil-rich plant source from which biodiesel is produced (Rashid et al., 2010). After oil extraction by screw press, the remaining seed cake is highly toxic to a number of animal species, probably due to the presence of phorbol esters and curcin, a type-I ribosome inactivating protein (Goel et al., 2007; Zhao etal., 2012). Protease inhibitor, lectin, and phytate are also present in high amounts (Saetae and Suntornsuk, 2011). Nevertheless, these compounds could be isolated and characterized to exploit their possible medicinal applications, as it was suggested that the J. curcas seed cake could be utilized as a source of antibacterial and antifungal agents (Sundari and Selvaraj, 2011).

Among these various molecules present in J. curcas seed cake, the protease inhibitors could be a potentially novel class of antimicrobial agents, as they specifically inhibit the catalytic action of enzymes by formation of stoichiometric complex with the target enzymes, blocking or altering its active site (Kim et al., 2009; Volpicella et al., 2011). In fact, protease inhibitors are found to be involved in various important physiological functions like regulators of endogenous proteinases and defense mechanism (Bhattacharjee et al., 2012). However, protease inhibitors also have received new interest due to their biological properties with 
potential for use as clinical agents. Of importance in the context of seeking plant protease inhibitors as novel therapeutic agents is that Xb-KTI, a Kunitz trypsin inhibitor present in Xanthosoma blandum corms with bactericidal activity (Lima et al., 2011). Similarly, the fistulin, a naturally occurring inhibitor of serine protease present in Cassia fistula leaves, showed to be very active against several pathogenic bacterial strains, namely, Staphylococcus aureus, Escherichia coli, Bacillus subtilis, and Klebsiella pneumoniae, and its efficacy was comparable to the standard drug, streptomycin sulfate (Arulpandi and Sangeetha, 2012).

To the best of our knowledge, a trypsin inhibitor from J. curcas seed cake has never been isolated neither its antibacterial activity tested yet. Thus, the present paper describes the purification and physicochemical characterization of a novel trypsin inhibitor from J. curcas seed cake, designated JcTI-I. Additionally, to gain better insights on the biological activity of this protein and to devise future use as a new therapeutic drugs, its inhibitory activity against the growth of the human pathogen bacteria Staphylococcus aureus and Salmonella enterica, as well as the ability of JcTI-I to inhibit the bacterial proteases were evaluated.

\section{MATERIALS AND METHODS MATERIALS}

Jatropha curcas seed cake was obtained from Instituto Fazenda Tamanduá (Paraíba, Brazil), grounded in a coffee grinder and passed through a $1-\mathrm{mm}$-mesh screen. The resulting flour was treated with $n$-hexane $(1: 5, \mathrm{~m} / \mathrm{v})$ to remove the remaining oil left after biodiesel extraction. Defatted flour was stored in air-tight containers at $4^{\circ} \mathrm{C}$ until analysis. The bacteria Salmonella enterica subspecies enterica serovar choleraesuis (ATCC 10708), Bacillus subtilis subspecies spizizenii (ATCC 6633), Pseudomonas aeruginosa (ATCC 25619), and Staphylococcus aureus (ATCC 25923) were obtained from the Department of Biology (UFC), Fortaleza, Brazil. Swiss mice (Mus musculus), 20-25 g, were from the animal house at UFC. Azocasein, bovine pancreatic trypsin, bovine pancreatic chymotrypsin, bovine serum albumin (BSA), soybean trypsin inhibitor (SBTI), N $\alpha$-benzoyl-D,L-arginina- $p$-naftilamida (BANA), 4-(dimethylamino)cinnamaldehyde (DMACA), ethylenediaminetetraacetic acid (EDTA), phenylmethylsulfonyl fluoride (PMSF), L-cysteine and N $\alpha$-benzoyl-D,L-arginine 4-nitroanilide hydrochloride (BAPNA), sodium dodecyl sulfate (SDS), molar mass markers, acrylamide, bis-acrylamide, dithiothreitol (DTT) were purchased from Sigma-Aldrich (St. Louis, MO, USA). Chromatographic matrixes were from GE Healthcare. All other chemicals and reagents used were of analytical grade.

\section{PROTEIN DETERMINATION}

The method described by Bradford (1976) was used with BSA as standard. Absorbance at $280 \mathrm{~nm}$ was also used to detect the presence of protein in the chromatographic eluates.

\section{TRYPSIN INHIBITION ASSAY}

Trypsin inhibitory activity against bovine trypsin (EC 3.4.21.4) was performed as described by Erlanger et al. (1961) using the chromogenic substrate BAPNA. The enzyme concentration used was established based on a dependent concentration assay and was that producing an absorbance between 0.25 and 0.30 in the enzymatic assay and reaction rate corresponding to $1 / 2 V_{\max }$. The inhibitory assay mixture consisted of $100 \mu \mathrm{L}$ of crude extract $(4.74 \mathrm{mg} / \mathrm{mL})$ or the purified inhibitor $(0.03 \mathrm{mg} / \mathrm{mL})$ dissolved in distilled water, incubated with $10 \mu \mathrm{L}$ of trypsin $(0.3 \mathrm{mg} / \mathrm{mL}$ in $10^{-3} \mathrm{M} \mathrm{HCl}$ ) and $690 \mu \mathrm{L}$ of $0.05 \mathrm{M}$ Tris- $\mathrm{HCl} / 0.02 \mathrm{M} \mathrm{CaCl}_{2}$, $\mathrm{pH} 7.5$, at $37^{\circ} \mathrm{C}$ for $10 \mathrm{~min}$. Next, $500 \mu \mathrm{L}$ of $1.25 \times 10^{-3} \mathrm{M}$ BAPNA dissolved in the above buffer were added and the mixture further incubated for $15 \mathrm{~min}, 37^{\circ} \mathrm{C}$. Reaction was stopped by addition of $120 \mu \mathrm{L}$ of $30 \%(\mathrm{v} / \mathrm{v})$ acetic acid. The enzymatic activities in the absence and presence of the inhibitor were evaluated by $p$-nitroanilide release from BAPNA measured at $410 \mathrm{~nm}$ using a Biochrom Libra S-12 spectrophotometer. One trypsin inhibitory activity unit (TIU) was defined as the decrease in $0.01 \mathrm{U}$ of absorbance per $15 \mathrm{~min}$ assay, at $37^{\circ} \mathrm{C}$. Appropriate blanks for the enzyme, inhibitor and the substrate were also included in the assay along with the test samples.

\section{PREPARATION OF THE PROTEIN EXTRACT}

Defatted flour was extracted with $0.1 \mathrm{M}$ borate buffer, $\mathrm{pH} 10.0$, in a proportion of $1.0 \mathrm{~g}$ of meal to $10.0 \mathrm{~mL}$ of buffer for $2 \mathrm{~h}$ under sonication, at $4^{\circ} \mathrm{C}$. Next the suspension was maintained under constant stirring for $2 \mathrm{~h}$ at $4^{\circ} \mathrm{C}$ and filtered through cheesecloth. The filtrate was centrifuged at $10,000 \times \mathrm{g}, 4^{\circ} \mathrm{C}, 30 \mathrm{~min}$ and the clear supernatant, denoted crude extract, was dialyzed (cut-off $12 \mathrm{kDa}$ ) against $0.050 \mathrm{M}$ sodium phosphate buffer, $\mathrm{pH}$ 7.5. The protein content and trypsin inhibitory activity of this dialyzed extract were determined and it was further used for purification of the trypsin inhibitor as described below.

\section{PURIFICATION OF J. curcas TRYPSIN INHIBITOR}

The crude extract prepared as described in Section "protein Determination" was fractionated by precipitation with $2.5 \%$ $(\mathrm{v} / \mathrm{v})$ trichloroacetic acid (TCA) final concentration, at $4^{\circ} \mathrm{C}$ and centrifuged at $14,000 \times g, 4^{\circ} \mathrm{C}, 30 \mathrm{~min}$. The clear supernatant obtained was dialyzed exhaustively against water (Milli-Q grade), lyophilized, and assayed for antitrypsin activity. The TCA fraction $(30 \mathrm{mg})$ was dissolved in $0.050 \mathrm{M}$ sodium phosphate buffer/0.2 $\mathrm{M} \mathrm{NaCl}, \mathrm{pH} 7.5$ and applied to a trypsin-Sepharose $4 \mathrm{~B}$ column $(11.5 \mathrm{~cm} \times 2.2 \mathrm{~cm})$ equilibrated with the above buffer. After complete removal of the non-retained proteins with the equilibrating buffer, the proteins bound to the immobilized trypsin were eluted with $0.1 \mathrm{M}$ $\mathrm{HCl}$, dialyzed exhaustively against water (Milli-Q grade) and lyophilized. This material (2 mg) was loaded on a Sephacryl S-200 column connected to an ÄKTA-Prime System (GE Healthcare) previously equilibrated and eluted with $0.050 \mathrm{M}$ sodium phosphate buffer/0.2 M NaCl, pH 7.5. Fractions (1 mL) were eluted at the flow rate of $0.5 \mathrm{~mL} / \mathrm{min}$ and the protein fractions obtained evaluated for trypsin inhibitory activity as described before. The purified trypsin inhibitor was named JcTI-I (J. curcas Trypsin Inhibitor I).

\section{CHARACTERIZATION OF JcTI-I Molecular mass determination}

The apparent molecular mass of JcTI-I was determined by denaturing electrophoresis [SDS-polyacrylamide gel electrophoresis 
(SDS-PAGE); Laemmli, 1970], in $12.5 \%(\mathrm{~m} / \mathrm{v})$ polyacrylamide gels $(10 \mathrm{~cm} \times 8 \mathrm{~cm})$. Samples were prepared in $0.5 \mathrm{M}$ Tris- $\mathrm{HCl}$ buffer, $\mathrm{pH} 6.8$, containing $1 \%$ SDS, in the presence or absence of $1 \% \beta$-mercaptoethanol and boiled at $98^{\circ} \mathrm{C}$, for $5 \mathrm{~min}$, before electrophoresis, which was performed at $20 \mathrm{~mA}$. Protein bands were stained with Coomassie Brilliant Blue G-250 (Candiano et al., 2004). The native molecular mass of JcTI-I ( $3 \mathrm{mg}$ ) was determined by gel filtration on Sephacryl S-200 column, coupled to an ÄKTA-Prime System (GE Healthcare) and equilibrated with $0.050 \mathrm{M}$ sodium phosphate buffer/0.2 M NaCl, $\mathrm{pH}$ 7.5. Chromatography was carried out at a constant flow rate of $0.5 \mathrm{~mL} / \mathrm{min}$ and $1 \mathrm{~mL}$ fractions were collected. Before loading on the column, the sample was centrifuged at $14,000 \times g$, $4^{\circ} \mathrm{C}$, for $5 \mathrm{~min}$ and the supernatant filtered through a Pro-X TM filter unit $(0.22 \mathrm{~mm}$ hydrophilic cellulose acetate membrane). The column was previously calibrated with proteins of known molecular mass (BSA, $66 \mathrm{kDa}$; egg albumin, $45 \mathrm{kDa}$; chymotrypsinogen, $25 \mathrm{kDa}$; ribonuclease, $13.7 \mathrm{kDa}$, and aprotinin, $6.5 \mathrm{kDa})$.

In addition, native mass was obtained by mass spectrometry analysis of JcTI-I $(0.1 \mathrm{mg} / \mathrm{mL})$ dissolved in water/acetonitrile $(1: 1, \mathrm{v} / \mathrm{v})$. The intact mass spectra was acquired in a Synapt G1 HDMS Acquity UPLC instrument (Waters Co., Milford, MA, USA) programmed with a RF offset (MS profile) adjusted such that the LC/MS data were effectively acquired from $\mathrm{m} / \mathrm{z} 400$ to 3,000 , which allowed to obtain multiply charged mass ions. Analysis was performed using a nanoelectrospray ionization in positive ion mode (ESI+) and a NanoLockSpray source. For all measurements, the mass spectrometer was operated in the "V" mode with a resolving power of at least $10,000 \mathrm{~m} / \mathrm{z}$. The data collection was performed using MassLynx 4.1 software (Waters Co., Milford, MA, USA) and charge distribution spectra were then deconvoluted by the Maximum Entropy Technique (MaxEnt). To assess whether JcTI-I is composed of subunits covalently linked by disulphide bridges it was previously treated with $0.1 \mathrm{M}$ DTT followed by $0.3 \mathrm{M}$ iodoacetamide and trypsin digestion to be analyzed by capillary liquid chromatography/nanoelectrospray ionization tandem mass spectrometry (ESI-LC-MS/MS), using the same equipment as described above, coupled with a nanohigh-performance liquid chromatography (UPLC) unit (Waters Co., Milford, MA, USA). The reduced and alkylated JcTI-I was injected using the nanoAcquity UPLC sample manager and the chromatographic separation was performed using an UPLC C18 column $(75 \mu \mathrm{m} \times 10 \mathrm{~cm})$ with a flow of $0.35 \mu \mathrm{L} / \mathrm{min}$. The mass spectra were acquired using a data-dependent acquisition (DDA) methodology, where the three top peaks were subjected to MS/MS. Mobile phases A and B consisted of $0.1 \%$ formic acid in water and $0.1 \%$ formic acid in acetonitrile, respectively. Column was equilibrated with $3 \%$ solution $\mathrm{A}$ and the gradient conditions used were as follows: $3-40 \%$ B for $20 \mathrm{~min}, 40-70 \%$ B for $40 \mathrm{~min}, 70 \%$ for further $50 \mathrm{~min}$ and $70-3 \%$ of $\mathrm{B}$ for $10 \mathrm{~min}$. The data were processed using the Protein Lynx Global Server (Waters Co., Milford, MA, USA) software and the searches made with the assumption that there was a maximum of one missed trypsin cleavage, peptides were mono-isotopic, methionine residues were partially oxidized and cysteine completely carbamidomethylated.

\section{Carbohydrate content}

The neutral sugar content of JcTI-I-I was estimated by the method of Dubois et al. (1956) using galactose as standard. To $250 \mu \mathrm{L}$ of JcTI-I-I $(0.20 \mathrm{mg} / \mathrm{mL}), 250 \mu \mathrm{L}$ of phenol $5 \%(\mathrm{v} / \mathrm{v})$ and $1.25 \mathrm{~mL}$ of concentrated sulfuric acid were added. The mixture was stirred and left at $25^{\circ} \mathrm{C}$ for $30 \mathrm{~min}$. Readings were taken at $490 \mathrm{~nm}$. The carbohydrate content was estimated based on a calibration curve built with different concentrations of galactose. The value is expressed in percentage (\%) of carbohydrate per protein mass. To confirm the presence of covalently bound carbohydrate in JcTI-I a specific staining of the protein bands after SDS-PAGE was carried out (Zacharius et al., 1969). Briefly, after the electrophoresis run the gel was fixed in a solution of $7.5 \%(\mathrm{v} / \mathrm{v})$ acetic acid for $2 \mathrm{~h}$, followed by incubation in a solution of $0.2 \%(\mathrm{v} / \mathrm{v})$ periodic acid, at $4^{\circ} \mathrm{C}$ for $45 \mathrm{~min}$ and incubation with the Schiff reagent at $4^{\circ} \mathrm{C}$ for further $45 \mathrm{~min}$. The glycoprotein nature of the band was revealed by immersion of the gel in a solution of $0.5 \%(\mathrm{~m} / \mathrm{v})$ potassium metabisulfite in $0.05 \mathrm{M} \mathrm{HCl}$.

\section{$\boldsymbol{N}$-terminal sequence analysis}

This was established in a Shimadzu PPSQ-10 Automated Protein Sequencer performing Edman degradation. Phenylthiohydantoin (PTH) amino acids were detected at $269 \mathrm{~nm}$ after separation on a reversed phase $\mathrm{C}_{18}$ column $(4.6 \mathrm{~mm} \times 2.5 \mathrm{~mm})$ under isocratic conditions, according to the manufacturer's instructions. Percentage sequence identity with trypsin inhibitors was searched for automatic alignment, performed using the NCBI-BLAST search system (Altschul et al., 1990).

\section{Effect of temperature, $\mathrm{pH}$, and salt}

This was evaluated according to Klomklao et al. (2011). JcTI-I $(0.035 \mathrm{mg} / \mathrm{mL})$ was diluted with distilled water to obtain $60-70 \%$ trypsin inhibition. For thermal stability assay, JcTI-I aliquots were incubated at $90^{\circ} \mathrm{C}$ for $0,10,20,30,40,50,60,90$, and $120 \mathrm{~min}$ and then cooled in ice-water. The trypsin inhibitory activity was determined and reported as the percentage of the residual activity compared to $70 \%$ trypsin inhibition. The effect of $\mathrm{pH}$ on JcTI-I stability was evaluated by measuring the residual activity after incubation at various $\mathrm{pH}$ values for $30 \mathrm{~min}$ at $25^{\circ} \mathrm{C}$. The buffers used were: $0.05 \mathrm{M}$ glycine- $\mathrm{HCl}, \mathrm{pH} 2.2 ; 0.05 \mathrm{M}$ sodium acetate, $\mathrm{pH} 5.2$; and $0.1 \mathrm{M}$ sodium borate, $\mathrm{pH}$ 10.0. The stability of JcTI-I to salinity was tested by incubating the trypsin inhibitor in $\mathrm{NaCl}$ solutions ranging from $0 \%$ up to $3 \%(\mathrm{~m} / \mathrm{v})$ concentration, at $25^{\circ} \mathrm{C}$ for $30 \mathrm{~min}$. After treatment the inhibitory activity against trypsin was determined as previously described and the residual inhibitory activity reported.

\section{Enzyme specificity}

The papain inhibitory assay was performed as described by Abe et al. (1992), using BANA as substrate. The enzyme concentration used was established based on a dependent concentration assay and was that producing an absorbance between 0.25 and 0.30 in the enzymatic assay and reaction rate corresponding to $1 / 2 V_{\max }$. To $60 \mu \mathrm{L}$ of papain $(0.02 \mathrm{mg} / \mathrm{mL}$ in $0.25 \mathrm{M}$ sodium phosphate buffer, pH 6.0), $40 \mu \mathrm{L}$ of the activation solution $\left(2 \times 10^{-3} \mathrm{M}\right.$ EDTA $+3 \times 10^{-3}$ M DTT, pH 6.0), $200 \mu \mathrm{L}$ of JcTI-I, and $200 \mu \mathrm{L}$ of $0.25 \mathrm{M}$ sodium phosphate buffer, $\mathrm{pH} 6.0$, were added. The 
mixture was incubated for $10 \mathrm{~min}$ at $37^{\circ} \mathrm{C}$. The reaction was initiated by addition of $200 \mu \mathrm{L} 0.001 \times 10^{-3} \mathrm{M}$ BANA, prepared in $1 \%(\mathrm{v} / \mathrm{v})$ dimethyl sulfoxide (DMSO) and $0.025 \mathrm{M}$ sodium phosphate buffer, $\mathrm{pH} 6.0$. After $20 \mathrm{~min}$ at $37^{\circ} \mathrm{C}$, the reaction was stopped by addition of $500 \mu \mathrm{L} 2 \%(\mathrm{v} / \mathrm{v}) \mathrm{HCl}$ in $95 \%(\mathrm{v} / \mathrm{v})$ ethanol. The color product was developed by adding $500 \mu \mathrm{L}$ of $0.06 \%(\mathrm{~m} / \mathrm{v})$ DMACA in ethanol and the absorbance was measured at $540 \mathrm{~nm}$. The chymotrypsin inhibitory activity was measured by the method of Erlanger et al. (1961), using azocasein as substrate. Twenty microliters of chymotrypsin $(0.1 \mathrm{mg} / \mathrm{mL}$ in $\left.2.5 \times 10^{-3} \mathrm{M} \mathrm{HCl}\right)$ was pre-incubated with JcTI-I $(0.2 \mathrm{mg} / \mathrm{mL})$

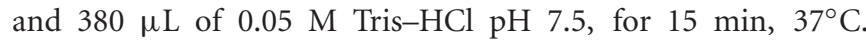
Next, $1 \%(\mathrm{~m} / \mathrm{v})$ azocasein was added to the mixture and incubated for $30 \mathrm{~min}$. Reaction was stopped by addition of $300 \mu \mathrm{L}$ $20 \%(\mathrm{v} / \mathrm{v}) \mathrm{TCA}$. After centrifugation $\left(10,000 \times \mathrm{g}, 10 \mathrm{~min}, 25^{\circ} \mathrm{C}\right)$, aliquots were withdrawn from the supernatants and added to $2 \mathrm{M}$ $\mathrm{NaOH}$, in an appropriate proportion, and the absorbance taken at $440 \mathrm{~nm}$.

\section{IC $\boldsymbol{C}_{\mathbf{5 0}}$ value and kinetic studies}

The amount of JcTI-I needed for 50\% inhibition of trypsin activity was determined as previously described in Section "Trypsin Inhibition Assay," but using the inhibitor in the concentration range of $1.0 \times 10^{-7}$ to $2.0 \times 10^{-7} \mathrm{M}$. Kinetic studies of protease inhibition by JcTI-I were conducted according to Bijina et al. (2011), with minor modifications, using bovine trypsin (molecular weight $23.3 \mathrm{kDa}$ ) and different concentrations of BAPNA $\left(8.0 \times 10^{-5}\right.$ to $\left.1.6 \times 10^{-3} \mathrm{M}\right)$. To calculate the kinetic parameters, JcTI-I at $5 \times 10^{-7}$ and $10 \times 10^{-7} \mathrm{M}$ concentrations and $8.0 \times 10^{-6} \mathrm{M}$ trypsin were previously incubated in $0.05 \mathrm{M}$ Tris- $\mathrm{HCl} / 0.02 \mathrm{M} \mathrm{CaCl}_{2}, \mathrm{pH} 7.5$, for $10 \mathrm{~min}$, at $37^{\circ} \mathrm{C}$, to reach the assay temperature. Then, $100 \mu \mathrm{L}$ fractions of JcTI-I were added to $10 \mu \mathrm{L}$ of the trypsin solution and further incubated for $10 \mathrm{~min}$, at $37^{\circ} \mathrm{C}$. Next, both the trypsin solution and trypsin + JcTI-I mixture were added separately to the BAPNA solutions and incubated at $37^{\circ} \mathrm{C}$, for $15 \mathrm{~min}$. Reaction was stopped by addition of $120 \mu \mathrm{L}$ of $30 \%(\mathrm{v} / \mathrm{v})$ acetic acid. The release of $p$-nitroanilide by the action of trypsin on BAPNA was measured at $410 \mathrm{~nm}$ as before. The velocity of enzyme reaction (v) was determined from progress curves using different BAPNA concentrations on the base of product concentrations measured at $410 \mathrm{~nm}$ at a fixed time of a reaction. To calculate $K_{\mathrm{m}}$ (Michaelis-Menten constant) and $V_{\max }$ (maximal rate) of the reaction and to study the pattern of inhibition, data were plotted as a function of BAPNA concentration using the usual non-linear curve fitting of Michaelis-Menten and linear Lineweaver-Burk, respectively. A secondary plot of $1 / K_{\mathrm{m}}$ versus JcTI-I concentrations was also drawn and the X-intercept used to calculate the dissociation constant $\left(K_{\mathrm{i}}\right.$; Cornish-Bowden, 1995).

\section{ANTIMICROBIAL ACTIVITY In vitro antibacterial activity}

The antibacterial activity (Hancock, 2000) of JcTI-I was tested in vitro against Salmonella enterica, Staphylococcus aureus, Bacillus subtilis, and Pseudomonas aeruginosa. The pathogenic bacteria were grown to mid-logarithm phase in $5 \mathrm{~mL}$ of Mueller-Hinton broth medium, at $37^{\circ} \mathrm{C}$. JcTI-I, at a $500 \mu \mathrm{g} / \mathrm{mL}$ final concentration, was prepared in $0.25 \mathrm{M}$ sodium phosphate buffer, $\mathrm{pH} 7.5$, and sterilized using a $0.22 \mu \mathrm{m}$ membrane, was incubated in 96-well flat microplates (Nunc) with $100 \mu \mathrm{L}$ of each bacterial suspension $\left(10^{5}-10^{6} \mathrm{CFU} / \mathrm{mL}\right)$ dissolved in the growth broth for $4 \mathrm{~h}$ at $37^{\circ} \mathrm{C}$. Bacterial growth was monitored at $630 \mathrm{~nm}$, every hour within the incubation period, using an automated microplate reader (BioTekElx800). The cell growth of both bacteria in the absence of JcTI-I was monitored as a blank control. Experiments were run in triplicate. To determine the minimum inhibitory concentration (MIC), JcTI-I, at 5-500 $\mu \mathrm{g} / \mathrm{mL}$ concentration, was dissolved in $0.25 \mathrm{M}$ sodium phosphate buffer, $\mathrm{pH} 7.5$ and $100 \mu \mathrm{L}$ incubated with equal volume of the bacterial cell suspension $\left(10^{5}-10^{6} \mathrm{CFU}\right)$ in wells of a 96-well polypropylene plate. The plates were kept for $4 \mathrm{~h}$ at $37^{\circ} \mathrm{C}$ and absorbance readings recorded at $630 \mathrm{~nm}$ every hour.

\section{Activity of JcTI-I against the Salmonella enterica and Staphylococcus aureus proteases}

The capacity of JcTI-I to inhibit the secreted and endogenous bacterial proteases was done following the methodology described by Lima et al. (2011) with minor modifications. Salmonella enterica and Staphylococcus aureus were cultured in $5 \mathrm{~mL}$ of MuellerHinton broth overnight, at $37^{\circ} \mathrm{C}$, and subcultured in $300 \mathrm{~mL}$ of Mueller-Hinton broth, at $37^{\circ} \mathrm{C}$ and $240 \mathrm{rpm}$, until the log phase was reached, as measured at $630 \mathrm{~nm}$ (Bio-TekElx800 reader). The bacterial cell cultures were collected at the late exponential growth phase by centrifugation at $4,000 \times \mathrm{g}$, for $15 \mathrm{~min}$, at $4^{\circ} \mathrm{C}$ and the pellet resuspended in the protease extraction solution $[\mathrm{HCl} 0.1 \%$ $(\mathrm{v} / \mathrm{v})+5.0 \times 10^{-3} \mathrm{M}$ Tris $+5.0 \times 10^{-3} \mathrm{M} \mathrm{CaCl}_{2}+0.1 \%(\mathrm{v} / \mathrm{v})$ Triton X-100, pH 7.5] and incubated in ice bath for $15 \mathrm{~min}$. Freezing and thawing took place three times, followed by centrifugation at $4,000 \times g$, for $30 \mathrm{~min}$, at $4^{\circ} \mathrm{C}$. The supernatants obtained, containing the protease from Salmonella enterica and Staphylococcus aureus, were pooled separately for every bacterium species and the serine protease activity as well as the inhibitory activity of JcTI-I assayed, according to the method previously described, using azocasein as substrate, bovine trypsin and PMSF as serine protease control inhibitor.

\section{HEMOLYTIC ACTIVITY ASSAY}

The hemolytic assay, performed in triplicate, was carried out as previously described (Kim et al., 2006), with minor modifications. Human red blood cells were collected in the presence of heparin, washed three times with phosphate-buffered saline (PBS; $3.5 \times 10^{-2} \mathrm{M}$ phosphate buffer containing $0.15 \mathrm{M} \mathrm{NaCl}$, $\mathrm{pH}$ 7.0) and recovered by centrifugation in the same buffer. The hemolytic activity of JcTI-I at $5-500 \mu \mathrm{g} / \mathrm{mL}$ concentration was evaluated by measuring the release of hemoglobin from fresh human erythrocytes. Aliquots $(25 \mu \mathrm{L})$ of a $2.5 \%$ suspension of red blood cells were transferred to 96-well plates and incubated with $25 \mu \mathrm{L}$ of JcTI-I for $30 \mathrm{~min}$, at $37^{\circ} \mathrm{C}$ followed by centrifugation at 5,000 $\times \mathrm{g}$, for $5 \mathrm{~min}$. Hemolysis (\%) was determined by measuring the supernatant absorbance at $540 \mathrm{~nm}$. PBS (0.05 M, pH 7.4) and 0.1\% (v/v) Triton X-100 were used, respectively, as negative ( $0 \%$ hemolysis) and positive ( $100 \%$ hemolysis) controls. 


\section{TOXICITY ASSAY}

The toxicity assay was reviewed and approved by the Animal Ethics Committee (CEPA) of UFC, Brazil, and realized according to the methodology described by Vasconcelos et al. (1994). Toxic activity was defined as mortality observed in Swiss mice within $24 \mathrm{~h}$ after intraperitoneal injections of JcTI-I at varied concentrations.

\section{STATISTICAL ANALYSIS}

The results are expressed as the mean \pm SEM. The statistical analysis was performed by one-way analysis of variance (ANOVA) followed by Tukey's multiple comparison tests. The results were considered to be significant at $P<0.05$.

\section{RESULTS}

\section{PURIFICATION OF JcTI-I}

Purification of JCTI-I encompassed TCA precipitation of the $J$. curcas protein extract followed by two additional chromatography steps. TCA, at $2.5 \%(\mathrm{v} / \mathrm{v})$ final concentration, precipitated the proteins with a recovery of up to $35.6 \%$ and 29.0 -fold purification of the trypsin inhibitor compared to the protein extract (Table 1). This TCA precipitated fraction was chromatographed on a trypsin-Sepharose $4 \mathrm{~B}$ affinity column and the adsorbed proteins, eluted with $0.1 \mathrm{M} \mathrm{HCl}$, concentrated the inhibitory activity that was specific for trypsin (Figure 1A), indicating that this chromatography step was important to exclude other protease inhibitors also present in the TCA precipitated fraction, as for papain (data not shown). At this stage, the trypsin inhibitor was purified to 331.5 -fold with a protein yield of $1.8 \%$ and specific activity of $6.63 \times 10^{-3} \mathrm{TIU} / \mathrm{mg}$ protein (Table 1 ). The fraction obtained from the trypsin-Sepharose $4 \mathrm{~B}$ affinity chromatography displaying trypsin inhibitory activity was composed of multiple protein bands as evaluated by SDS-PAGE (Figure 1A; insert: lane 3). Therefore, this fraction was further purified on a Sephacryl S200 column (Figure 1B). The eluted protein present in the major peak showed a specific activity of $28.35 \times 10^{-3} \mathrm{TIU} / \mathrm{mg}$ protein, 1417.5 -fold purification, but a low protein yield of $1.2 \%$. Nevertheless, it was homogeneous by SDS-PAGE as it presented a unique protein band with a relative molecular mass around of $20.0 \mathrm{kDa}$ (Figure 1B, insert: lane 2). This purified protein is a trypsin inhibitor of J. curcas seed cake that was denominated JcTI-I thereafter.

\section{CHARACTERIZATION OF JcTI-I Molecular mass determination, pl, carbohydrate content, and N-terminal sequence}

Native molecular mass of JcTI-I was assessed by gel filtration chromatography on Sephacryl S-200 column. A molecular mass of $20.2 \mathrm{kDa}$ was calculated for the inhibitor dissolved in $0.05 \mathrm{M}$

Table 1 | Purification steps of a trypsin inhibitor from J. curcas cake.

\begin{tabular}{|c|c|c|c|c|c|}
\hline Steps & Total protein ${ }^{a}$ (mg) & $\begin{array}{l}\text { Total activity } \\
\left(\text { TIU } \times 10^{-3}\right)\end{array}$ & $\begin{array}{l}\text { Specificity activity } \\
\left(\text { TIU/mg protein } \times 10^{-3} \text { ) }\right.\end{array}$ & Yield $^{\mathrm{c}}(\%)$ & $\begin{array}{l}\text { Purification } \\
\text { index }^{d}\end{array}$ \\
\hline Crude extract & 165.6 & 4.1 & 0.02 & 100 & 1.0 \\
\hline $\mathrm{F}_{2.5}(\mathrm{TCA})$ & 59.0 & 34.4 & 0.58 & 35.6 & 29.0 \\
\hline Trypsin-Sepharose 4B & 3.0 & 19.9 & 6.63 & 1.8 & 331.5 \\
\hline Sephacryl S-200 & 2.0 & 56.7 & 28.35 & 1.2 & 1417.5 \\
\hline
\end{tabular}

Results are presented as mean values of three replications.

a The total amount of protein recovered from $1 \mathrm{~g}$ of defatted flour from $\mathrm{J}$. curcas seed cake.

b One trypsin inhibitory activity unit (TIU) was defined as the decrease in $0.01 \mathrm{U}$ of absorbance per 15 min assay, at $37^{\circ} \mathrm{C}$.

${ }^{\mathrm{c}}$ The recovery of protein at each purification step (crude extract, 100\%).

$\mathrm{d}$ Purification index is calculated as the ratio between the specificity activity obtained at each purification step and that of the crude extract taken as 1.0 .

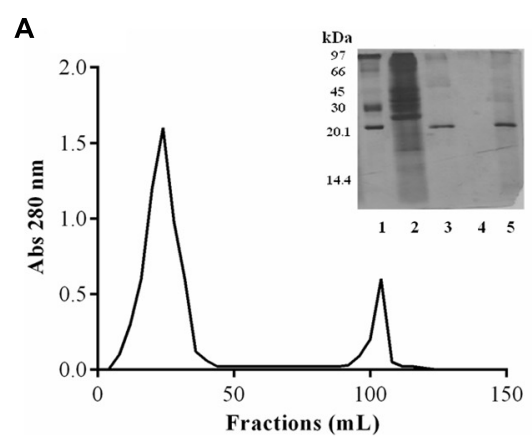

FIGURE 1 | JcTI-I purification. (A) Affinity-chromatography (TrypsinSepharose 4B column). Inset: SDS-PAGE: (1) molar mass markers; (2) crude extract; (3) 2.5\% TCA fraction; (4) unbound fractions; (5) bound fractions. (B) Size exclusion chromatography (Sephacryl S-200 column) of JcTI-I purified

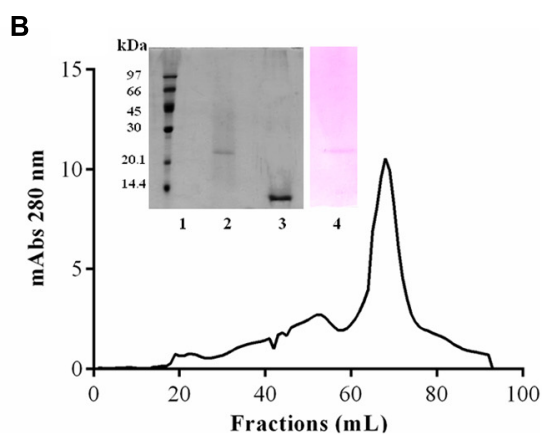

after chromatography on Trypsin-Sepharose 4B column. Inset: SDS-PAGE: (1) molar mass markers; ( 2 and 3$) \mathrm{JcTl}-\mathrm{I}(5 \mu \mathrm{g})$ in the absence and presence of $1 \% \beta$-mercaptoethanol, respectively; (4) JcTI-I (5 $\mu \mathrm{g})$ stained with Schiff's reagent. 
sodium phosphate buffer, $\mathrm{pH} 7.5$, containing $0.2 \mathrm{M} \mathrm{NaCl}$. This value is very similar compared to the molecular mass obtained by SDS-PAGE in the absence of reducing agents (Figure 1B, insert: lane 2). However, ESI mass spectrometry under native conditions, with JcTI-I dissolved in water/acetonitrile $(1: 1, \mathrm{v} / \mathrm{v})$, revealed a $10.252 \mathrm{kDa}$ polypeptide (Figure $2 \mathrm{~A}$ ) which is very close to the molecular mass of JcTI-I found under denaturing condition in the presence of $\beta$-mercaptoethanol (Figure 1B; insert: lane 3) and after two-dimensional (2D) gel electrophoresis that also showed a pI of 6.6 (data not shown) for the

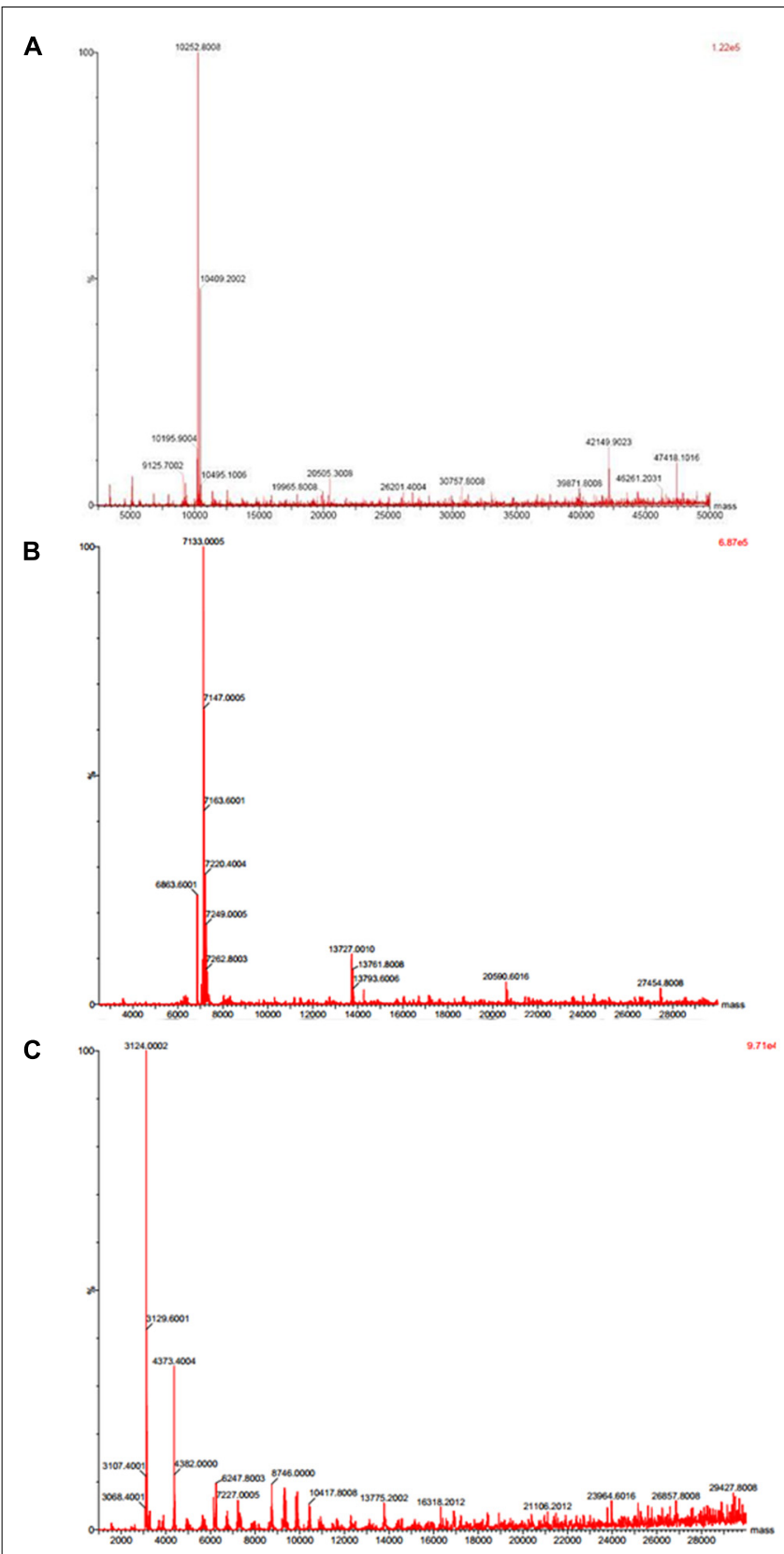

FIGURE 2 | Mass spectrometry analysis of JcTI-I. (A) Native JcTI-I; $(\mathbf{B}, \mathbf{C}) \mathrm{JcTI}-\mathrm{I}$ previously reduced and alkylated with DTT and iodoacetamide, respectively. purified inhibitor. DTT reduced and alkylated JcTI-I produced two derived peptides of 7.133 and $3.124 \mathrm{kDa}$, after MS/MS analysis, suggesting that these polypeptides are linked by disulfide bond (Figures 2B,C, respectively). Moreover, JcTI-I has 6.4\% covalently linked carbohydrate (Figure 1B; insert: lane 4) and an N-terminal sequence of VRDICKKEAERRDLSSCENYITQRRGY (Table 2). This sequence was confirmed after mass spectrometry analysis of JcTI-I (Table 3). Alignment of this $\mathrm{N}$-terminal sequence with known sequences in the NCBI nonredundant database showed 68 and 58\% similarity with an allergenic $2 \mathrm{~S}$ albumin from $J$. curcas seeds and with an albumin $2 \mathrm{~S}$ from Ricinus communis, respectively. In addition, other peptide sequences were obtained similar to $2 \mathrm{~S}$ albumins, particularly from $R$. communis (Table 3 ). However, no similarity was found between the N-terminal sequence of JcTI-I generated by Edman degradation and the peptide sequences obtained by MS/MS analysis with known members of the protease inhibitor family.

\section{Thermal and $\mathrm{pH}$ stability}

Heating of JCTI-I at $90^{\circ} \mathrm{C}$ for up to 20 min induced a slight increased in the inhibitory activity upon trypsin as compared to $70 \%$ trypsin inhibition of the native inhibitor (Figure 3A). Afterward the heat treatment for up to $120 \mathrm{~min}$ had little consequence on the inhibitory effect of JcTI-I as it was reduced only to around $4-5 \%$ of that of the untreated inhibitor. Incubation of JcTI-I at the $\mathrm{pH}$ range of 2.0-10.0 (Figure 3B) had overall a slight inducing effect $(10 \%)$ on inhibition (Figure 3B), except at $\mathrm{pH} 5.0$ that maintained $70 \%$ trypsin inhibition. Incubation of JcTI-I with different concentrations of salt (0-3\%) showed that the protein retained approximately its original activity up to $2.0 \% \mathrm{NaCl}$ concentration (Figure 3C). However, at $2.5 \% \mathrm{NaCl}$ concentration an $11.6 \%$ reduction in the inhibitory activity was noticed (Figure 3C), whereas at 3.0\% the trypsin inhibition was $10 \%$ higher than the $70 \%$ inhibition induced by the untreated inhibitor.

\section{Enzyme specificity}

JcTI-I was specific for inhibiting bovine trypsin, but did not inhibit significantly chymotrypsin and papain.

\section{$I_{50}$ value and kinetic parameters}

The data obtained for the studies conducted on proteaseprotease inhibitor interaction is depicted in Figure 4. The amount of inhibitor needed for 50\% trypsin inhibition $\left(\mathrm{IC}_{50}\right)$ was $1.25 \times 10^{-6} \mathrm{M}$. Moreover, it is calculated that the stoichiometry of trypsin-protease inhibitor interaction is $1: 1.7$. Kinetic studies of inhibition of trypsin by JcTI-I showed that plots of a fixed concentration of trypsin $\left(8.0 \times 10^{-6} \mathrm{M}\right)$ preincubated with the buffer alone (control) and with 0.5 and $1.0 \times 10^{-6} \mathrm{M}$ of JcTI-I produced different slopes of $1 / v$ versus $1 /$ [s] (Figure 5). These data indicated a non-competitive mechanism of action of JcTI-I as lines are converging to the same point on the $1 /[\mathrm{S}]$ axis where $K_{\mathrm{m}}$ is unchanged, whereas $V_{\max }$ is reduced. Furthermore, calculated $K_{\mathrm{i}}$ (Figure 5, insert) was on average $0.24 \times 10^{-6} \mathrm{M}$, indicating that inhibition of the trypsin hydrolysis by JcTI-I occurred at very low concentration characterizing a very potent inhibitor. 
Table 2 | Comparison of $\mathrm{N}$-terminal sequence of JcTI-I with similar protein sequences.

\begin{tabular}{|c|c|c|c|c|}
\hline Protein & Species & $\mathrm{N}$-terminal sequence & Identity (\%) & Access number ${ }^{a}$ \\
\hline JcTI-I & Jatropha curcas & VRDICKKEAERRDLSSCENYITQRRGY & & $\mathrm{COHJF7}{ }^{\mathrm{b}}$ \\
\hline Precursor albumin $2 \mathrm{~S}$ & Ricinus communis & CROEIORKDLSSCEOYIROSSSRR & 58 & XP_002522851 \\
\hline Glycine-rich protein & Arabidopsis thaliana & DIAKKKTKKKDLSSSDNYFTKR & 55 & NP_683354 \\
\hline
\end{tabular}

a Results of a BLAST search.

b UniProt accession number of JCTl-I.

${ }^{c}$ Deduced amino acid sequence of Jat c $1^{\text {b }}$, a allergenic $2 S$ albumin (Maciel et al., 2009).

Table 3 | Peptide sequences of JcTI-I identified after data-dependent acquisition (DDA) analysis.

\begin{tabular}{llcll}
\hline $\boldsymbol{m} / \boldsymbol{z}$ & Charge & Delta (ppm) & Sequence & Modifications \\
\hline 821.3901 & 2 & 4.091931 & (R)RDLSSCENYITQR(R) & Carbamidomethyl C (6) \\
743.3438 & 2 & 10.359877 & (R)DLSSCENYITQR(R) & Carbamidomethyl C (5) \\
424.7177 & 2 & -2.8809798 & (K)ELSAICR(C) & Carbamidomethyl C (6) \\
646.3268 & 2 & 7.850316 & (R)CESIHYLLEK(Q) & Carbamidomethyl C (1) \\
774.3472 & 2 & 2.6834285 & (K)QLEEGEVGSEDEAR(R) & \\
\hline
\end{tabular}

\section{ANTIMICROBIAL ACTIVITY OF JcTI-I}

JcTI-I did not affect the growth of Bacillus subtilis and Pseudomonas aeruginosa, even at a concentration of $500 \mu \mathrm{g} / \mathrm{mL}$ (data not shown). However, the protein inhibited the growth of Staphylococcus aureus and Salmonella enterica at all concentrations tested when compared to controls. The MIC was calculated as $5 \mu \mathrm{g} / \mathrm{mL}$ for both bacteria (Figures 6A,B). Moreover, JcTI-I caused $84.6 \%$ and almost $100 \%$ inhibition of the proteases extracted from Staphylococcus aureus and Salmonella enterica, respectively, values similar to that found for protein sparing modified fast (PSMF; Figure 7).

\section{ASSESSMENT OF HEMOLYTIC ACTIVITY OF JcTI-I}

JcTI-I did not promote hemolysis of human erythrocyte under the experimental conditions tested (Figure 8).

\section{ASSESSMENT OF TOXIC ACTIVITY OF JcTI-I}

JcTI-I did not display toxic activity to mice, even at a concentration 100 times greater than the MIC for Staphylococcus aureus and Salmonella enterica.

\section{DISCUSSION}

Purification of a novel trypsin inhibitor (JcTI-I) from J. curcas seeds cake was achieved by TCA precipitation of the protein extract followed by two chromatographic steps. JcTI-I is a $10.252 \mathrm{kDa}$ neutral glycosylated protein with a $\mathrm{p} I$ of 6.6 and $6.4 \%$ of carbohydrate. Both the molecular mass and $\mathrm{p} I$ are similar to other seed trypsin inhibitors previously characterized as, for example, the $10.0 \mathrm{kDa}$ trypsin inhibitor from Zea mays (Baker et al., 2009) and that purified from Phaseolus limensis seeds, with $\mathrm{p} I$ of 7.6 (Wang and Rao, 2010).
Analyzing the results of both SDS-PAGE and MS/MS, it appears that the $10.252 \mathrm{kDa}$ JcTI-I molecule is composed of a 7.133 and $3.124 \mathrm{kDa}$ polypeptides jointed together by at least one disulphide bridge and that DTT + iodoacetamide treatments, but not $\beta$-mercaptoethanol alone, were able of irreversibly splitting the molecule in the small and large subunits. The results of size exclusion chromatography of JcTI-I on Sephacryl S-200 gave a $20.2 \mathrm{kDa}$ molecule. It is plausible that under such mild conditions in which JcTI-I was dissolved in $0.050 \mathrm{M}$ sodium phosphate buffer containing $0.2 \mathrm{M} \mathrm{NaCl}, \mathrm{pH} 7.5$, the $10.252 \mathrm{kDa}$ monomer associated to form a $20.2 \mathrm{kDa}$ dimer, which does not occur in the presence of acetonitrile in the MS/MS analysis.

Alignments of JcTI-I sequence with other protein sequences showed that the highest similarity was verified with Jat $\mathrm{c} 1$, a $J$. curcas allergen that belongs to the $2 \mathrm{~S}$ albumin family (Maciel et al., 2009), but not with known protease inhibitor sequences. Several trypsin inhibitors show sequence similarities with the $2 S$ albumin-like proteins, as two barley Bowman-Birk type trypsin inhibitor isoforms and the trypsin inhibitor of Brassica juncea seeds (Terras et al., 1993; Mandal et al., 2002). Therefore, JcTI-I might be a novel trypsin inhibitor that belongs to the $2 \mathrm{~S}$ albumin family.

Protease inhibitors exhibit a considerable stability to high temperatures and to large $\mathrm{pH}$ variations (Bhattacharyya et al., 2006; Bijina et al., 2011). JcTI-I has also these common properties as it was active and stable after incubation at $90^{\circ} \mathrm{C}$ for $60 \mathrm{~min}$ and in the $\mathrm{pH}$ range $2.0-10.0$, in agreement with other plant protease inhibitors. Moreover, JcTI-I was stable to high salt concentrations as it retained full activity after treatment with up to $2 \% \mathrm{NaCl}$. The trypsin inhibitor purified from adzuki bean (Vigna angularis) seeds was also stable when 


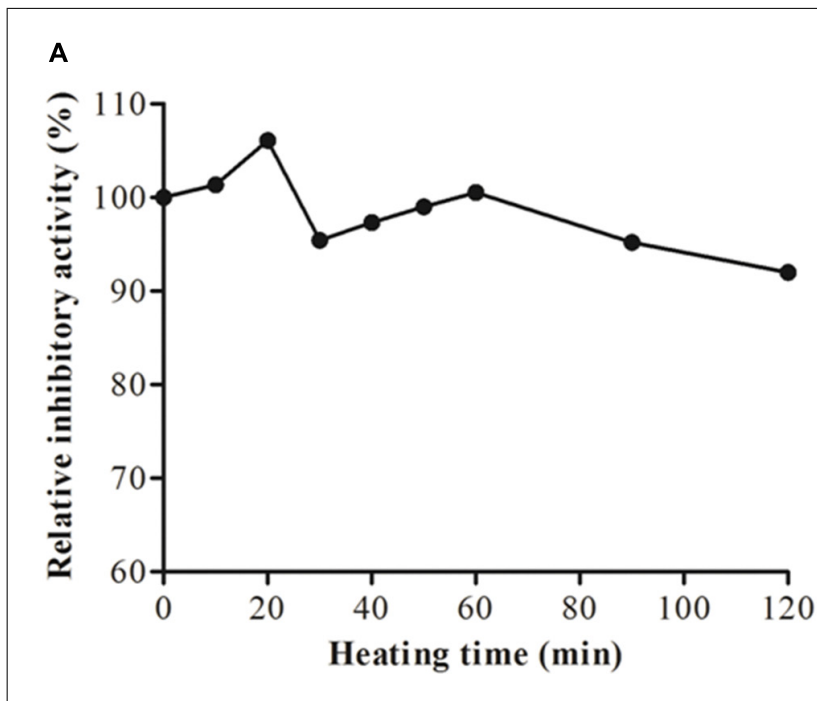

B

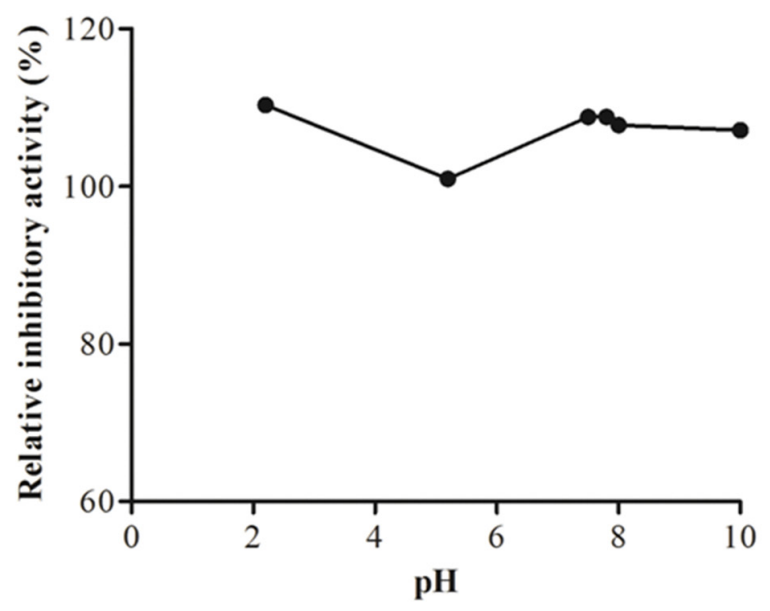

C

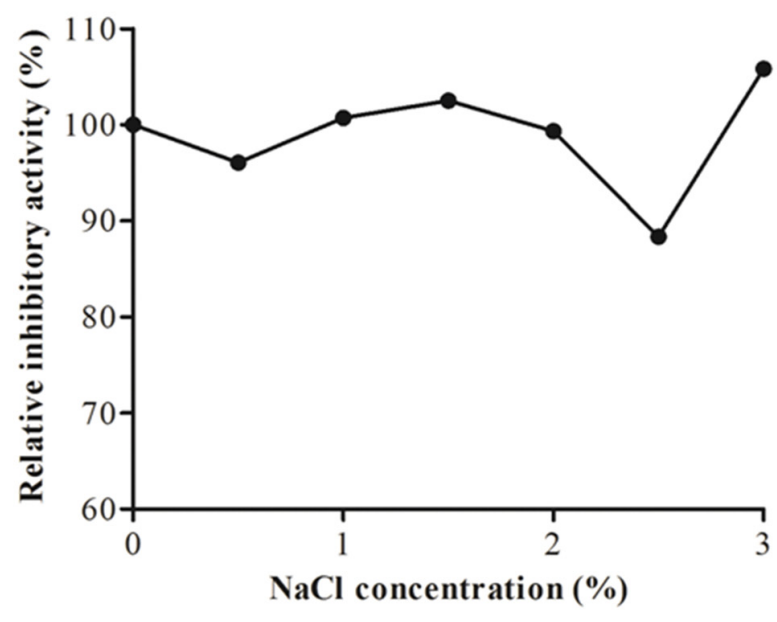

FIGURE 3 | Trypsin inhibitory activity assay of JcTI-I at pH 7.5, at room temperature (around $25^{\circ} \mathrm{C}$ ) after: (A) heat-treatment; (B) incubation at pH 2-10 for $30 \mathrm{~min}$; (C) incubation with 0-3 M NaCl concentration.

Each point represents the mean of three estimates. The standard deviation was less than $10 \%$.
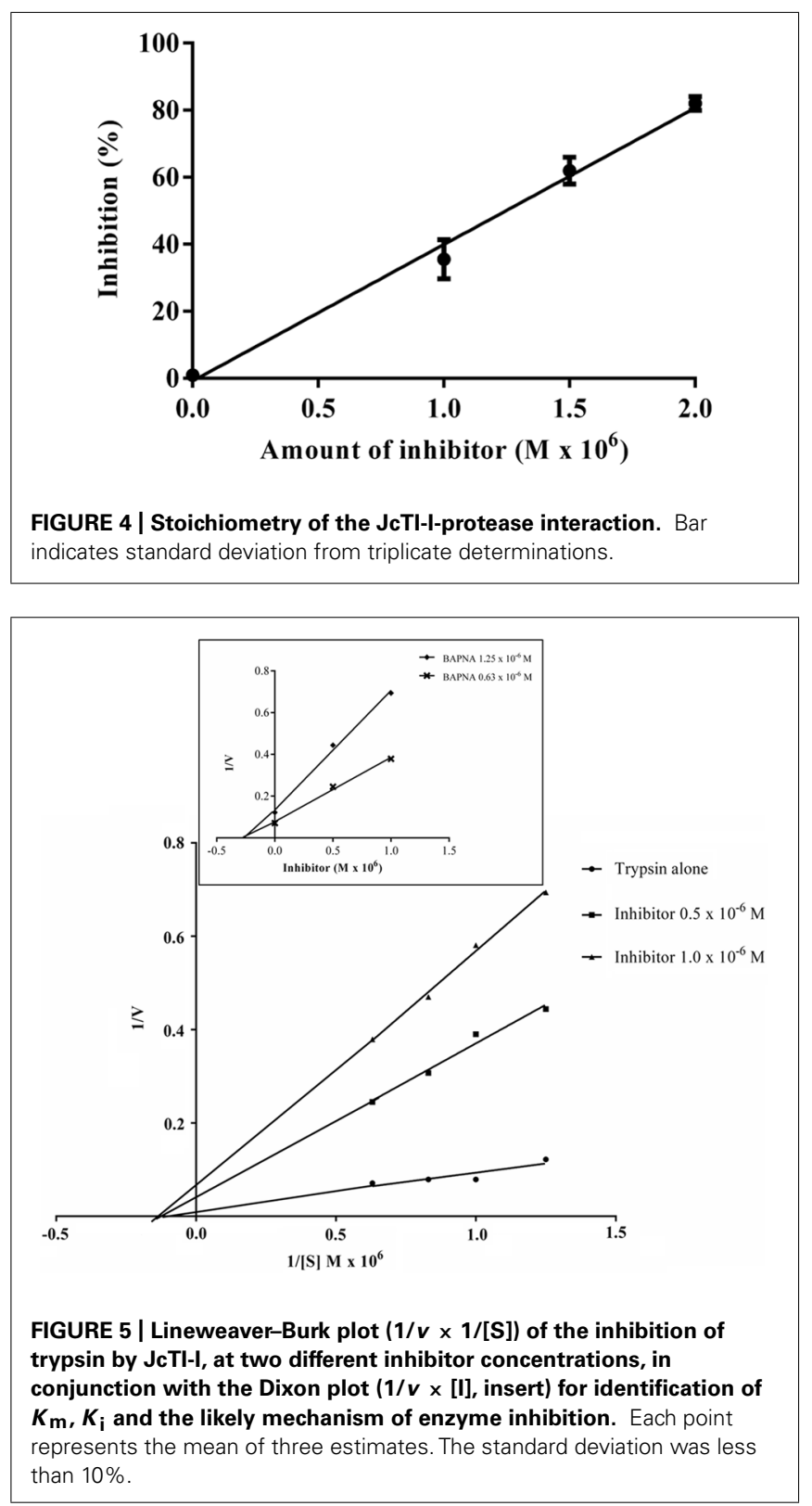

incubated with $\mathrm{NaCl}$ up to $3 \%$ concentration (Klomklao et al., 2011). Such stability was associated to disulphide bridges that are presumably responsible for the functional stability of Kunitz type protease inhibitors in the presence of physical and chemical denaturants such as temperature, $\mathrm{pH}$, and reducing agents (Kridric et al., 2002).

JcTI-I is a non-competitive trypsin inhibitor similar to other trypsin inhibitors, such as AETI, APTI, and TTI from the seeds of Archidendron ellipticum (Bhattacharyya et al., 2006), Adenanthera pavonina (Macedo et al., 2004), and Tamarindus indica (Araújo etal., 2005), respectively. The $\mathrm{IC}_{50}$ of JcTI-I for trypsin was $1.25 \times 10^{-6} \mathrm{M}$, indicating that it was more potent than EvTI, the trypsin inhibitor from Erythrina velutina seeds $\left(\mathrm{IC}_{50}=2.2 \times 10^{-6} \mathrm{M}\right.$; Machado et al., 2013) and less than SSTI2, the trypsin inhibitor from Sapindus saponaria seeds 
A

\section{S. aureus}

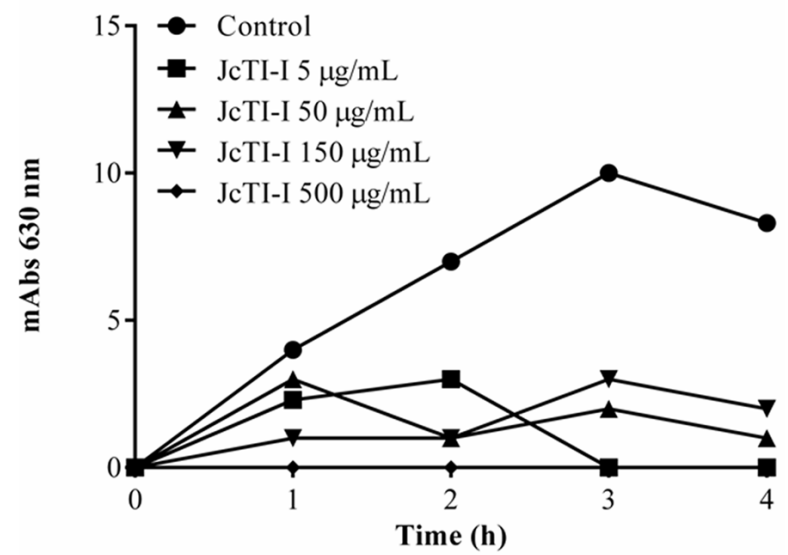

B

\section{S. enterica}

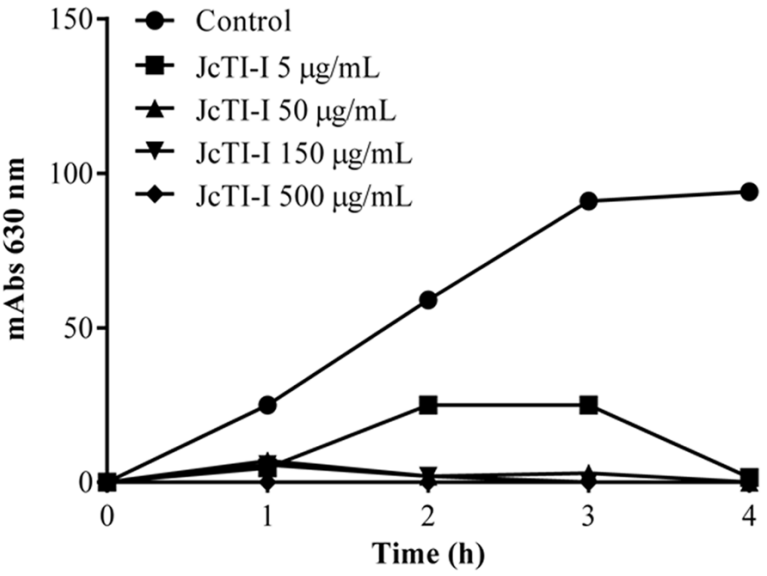

FIGURE 6 | Effect of JcTI-I at different concentrations on the growth of Staphylococcus aureus (A), and Salmonella enterica (B). Control: $0.05 \mathrm{M}$ sodium phosphate buffer ( $\mathrm{pH}$ 7.5). The minimal inhibitory concentration (MIC) of JcTI-I was determined based on these data. Assay was done in triplicate for every inhibitor concentration. The standard deviation was less than $10 \%$

$\left(\mathrm{IC}_{50}=8.3 \times 10^{-8} \mathrm{M}\right.$; Macedo et al., 2011). JcTI-I interaction with trypsin occurred at the 1:1.7 molar ratio, indicating a 1:2 stoichiometry, with two equivalent binding sites. Similar result was found for a protease inhibitor from Moringa oleifera leaves (Bijina et al., 2011). The inhibition constant $\left(K_{\mathrm{i}}\right)$ for JcTI-I was $2 \times 10^{-11} \mathrm{M}$ under the assay conditions. Low $K_{\mathrm{i}}$ values were also found for the trypsin inhibitors CBTI-2 from Caesalpinia bonduc (Bhattacharyya et al., 2007) and AETI (Bhattacharyya et al., 2006) with $K_{\mathrm{i}}$ of 2.4 and $2.7 \times 10^{-10} \mathrm{M}$, respectively.

Resistance of some strains of Gram-positive and Gram-negative bacteria to conventional antibiotics has increased dramatically caused or induced by the widespread misuse and overuse of antibiotics and represents a serious threat to public health worldwide. Therefore, discovery and/or development of alternative,
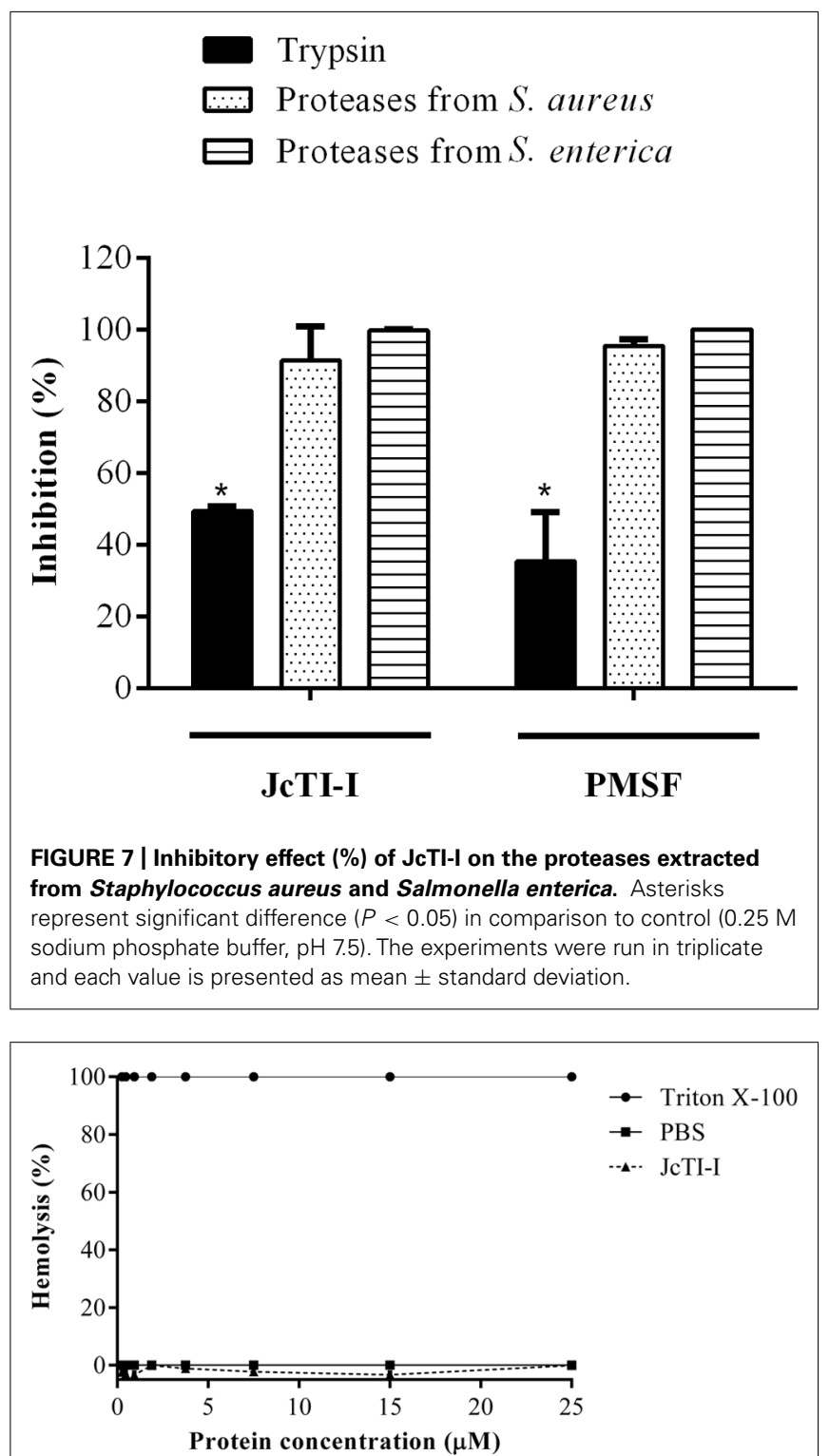

FIGURE 8 | Assessment of the hemolytic effect of JcTI-I on human erythrocytes. A suspension of washed human erythrocytes was incubated with various concentrations of $\mathrm{JcTI}-\mathrm{I}(-\mathbf{\Delta}-)$. Values $\left(\mathrm{OD}_{540}\right)$ were normalized against $100 \%$ lysed erythrocytes $(0.1 \%$ Triton X-100) (-•-). Control was the red cells incubated with 0.05 M PBS, pH 7.4 (-口-). Each point represents the mean of three estimates. The standard deviation was less than $10 \%$.

non-conventional drugs with activity against most resistant bacteria for infection control are of paramount importance (Lima et al., 2011). J. curcas is a plant traditionally used for medicinal purposes and its antimicrobial potential has been previously reported. Indeed, extracts from leaves, root barks, latex, and various fruit parts of $J$. curcas showed inhibitory activity against $E$. coli, Staphylococcus aureus, Pseudomonas aeruginosa, and Bacillus subtilis (Arekemase et al., 2011; Nyembo et al., 2012; Rachana et al., 2012). However, few reports are related to the antimicrobial activity of compounds present in the seed cake of J. curcas, although its potential use as a source of antibacterial agents has 
been suggested (Sriprang et al., 2010; Sundari and Selvaraj, 2011). The seed cake of J. curcas represents an attractive raw material to extract novel antibacterial drugs because it is produced in large scale as a waste material after oil extraction to produce biodiesel. It is estimated that 1-tn per day of J. curcas extracted oil generates, approximately, 3 tn of seed cake (Srividhya et al., 2010).

The use of protease inhibitors as novel therapeutics has previously been proposed (Bhattacharjee et al., 2012; Machado et al., 2013). Therefore, take into consideration the huge amount of J. curcas seed cake generated, from which JcTI-I was purified, the hypothesis that it could behave as a natural drug against human pathogens was also tested. This was experimentally confirmed as JcTI-I behaved as a potent inhibitor of Staphylococcus aureus and Salmonella enterica growth. The MIC of JcTI-I for both bacteria was $5 \mu \mathrm{g} / \mathrm{mL}$. This concentration is sixfold lower compared with that found for a potato inhibitor effective against various bacteria, including Staphylococcus aureus with a MIC around $30 \mu \mathrm{g} / \mathrm{mL}$ (Kim et al., 2006), about 50-fold lower than that of Xb-KTI, a kunitz proteinase inhibitor from X. blandum corms, active against Salmonella typhimurium, with a MIC of about $256 \mu \mathrm{g} / \mathrm{mL}$ (Lima et al., 2011) and about 25-fold lower than that of cloxacillin, a $\beta$-lactam antibiotic used as therapeutic drug against MRSA with a MIC around $128 \mu \mathrm{g} / \mathrm{mL}$ (Islam et al., 2008). According to Hancock (2000), the best protein/peptide candidates for antibacterial drugs have MICs ranging from 1 to $8 \mu \mathrm{g} / \mathrm{mL}$. Based on these results, JcTI-I can be considered as a potent inhibitor of bacterial growth and could be explored as an antibiotic protein to help bring down the 10$30 \%$ mortality caused by Staphylococcus aureus (van Hal et al., 2012).

Serine proteases have been implicated in the virulence of some bacterial strains (Speranskaya etal., 2006; Tripathi et al., 2011). Therefore, substances that can interfere with the proteolytic activity of these enzymes, like protease inhibitors, could be an effective strategy to combat bacterial infections (González-Lamothe et al., 2009). JcTI-I did have inhibitory activity against the serine proteases from the tested bacteria. It caused about 85 and 100\% inhibition of the proteases extracted from Staphylococcus aureus and Salmonella enterica, respectively, values compared to those achieved by PSMF, a synthetic inhibitor. These results are similar to that reported by Lima et al. (2011) who found that Xb-KTI caused about $80 \%$ inhibition of the serine proteases from Salmonella typhimurium.

To assess whether JcTI-I promotes lysis of eukaryotic cells, this protease inhibitor was incubated with human erythrocytes up to the concentration of $500 \mu \mathrm{g} / \mathrm{mL}$, about 100 -fold higher than the MIC of JcTI-I $(5 \mu \mathrm{g} / \mathrm{mL})$ for both bacteria. Even at such concentration, JcTI-I does not lysis the red cells. This result suggests that the mode of action of JcTI-I is not by disrupting cell membranes and it does not have toxic effects toward mammalian cells. In addition, JcTI-I was not toxic to mice at a concentration very much higher than the MIC for Staphylococcus aureus and Salmonella enterica.

In summary, we have isolated, purified, and characterized a novel trypsin inhibitor from J. curcas seed cake, named JcTI-I, which possesses a potent activity against the human pathogenic bacteria Staphylococcus aureus and Salmonella enterica. The lack of hemolytic activity against human erythrocytes and toxic activity to mice together with resistance to heat treatment, $\mathrm{pH}$, high salt concentrations, and putative resistance to proteases make JcTI-I a pharmacologically interesting and valuable drug for the design of a novel antibiotic medicament.

\section{ACKNOWLEDGMENTS}

This work was supported by Conselho Nacional de Desenvolvimento Científico e Tecnológico (CNPq), Coordenação de Aperfeiçoamento de Pessoal de Nível Superior (CAPES), and Fundação Cearense de Apoio ao Desenvolvimento Científico e Tecnológico (FUNCAP).

\section{REFERENCES}

Abe, M., Abe, K., Kuroda, M., and Arai, S. (1992). Corn kernel cysteine proteinase inhibitor as a novel cystatin superfamily member of plant origin: molecular cloning and expression studies. Eur. J. Biochem. 209, 933-937. doi: 10.1111/j.1432-1033.1992.tb17365.x

Altschul, S. F., Gish, W., Miller, W., Myers, E. W., and Lipman, D. J. (1990). Basic local alignment search tool. J. Mol. Biol. 215, 403-410.

Araújo, C. L., Bezerra, I. W. L., Oliveira, A. S., Moura, F. T., Macedo, L. L. P., Gomes, C. E. M., et al. (2005). In vivo bioinsecticidal activity toward Ceratitis capitata (fruit fly) and Callosobruchus maculatus (Tamarindus indica). J. Agric. Food Chem. 53, 4381-4387. doi: 10.1021/jf0502505

Arekemase, M. O., Kayode, R. M. O., and Ajiboye, A. E. (2011). Antimicrobial activity and phytochemical analysis of Jatropha curcas plant against some selected microorganisms. Int. J. Biol. 3, 52-59. doi: 10.5539/ijb. v3n3p52

Arulpandi, I., and Sangeetha, R. (2012). Antibacterial activity of fistulin: a protease inhibitor purified from the leaves of Cassia fistula. ISRN Pharm. 2012, 84073. doi: 10.5402/2012/584073

Baker, R. L., Brown, R. L., Chen, Z.-Y., Cleveland, T. E., and Fakhoury, A. M. (2009). A maize trypsin inhibitor (ZmTIp) with limited activity against Aspergillus flavus. J. Food Prot. 72, 185-188.

Becker, P., Santos, O., Castrucci, F. M., Dias, C., and D’Azevedo, P. A. (2012). First report of methicillin-resistant Staphylococcus aureus Cordobes/Chilean clone involved in nosocomial infections in Brazil. Epidemiol. Infect. 140, 1372-1375 doi: 10.1017/S095026881100210X

Bhattacharjee, C., Prasad, D. T., Manjunath, N. H., Sanyal, D., and Zarga, S. M. (2012). Exploring plant proteinase inhibitors. Genomics Appl. Biol. 3, 8-21. doi: 10.3969/gab.2012.03.0002

Bhattacharyya, A., Mazumdar, S., Leighton, S., and Babu, C. (2006). A Kunitz proteinase inhibitor from Archidendron ellipticum seeds: purification, characterization, and kinetic properties. Phytochemistry 67, 232-241. doi: 10.1016/j.phytochem.2005.11.010

Bhattacharyya, A., Rai, S., and Babu, C. R. (2007). A trypsin and chymotrypsin inhibitor from Caesalpinia bonduc seeds: isolation, partial characterization and insecticidal properties. Plant Physiol. Biochem. 45, 169-177. doi 10.1016/j.plaphy.2007.02.003

Bijina, B., Chellappana, S., Basheera, S. M., Elyasa, K. K., Bahkalic, A. H., and Chandrasekarana, M. (2011). Protease inhibitor from Moringa oleifera leaves: isolation, purification, and characterization. Process Biochem. 46, 2291-2300. doi: 10.1016/j.procbio.2011.09.008

Bradford, H. H. (1976). A rapid and sensitive method for the quantification of microgram quantities of protein using the principle of protein dye binding. Anal. Biochem. 72, 248-254. doi: 10.1016/0003-2697(76)90527-3

Broughton, E. I., Ip, M., Coles, C. L., and Walker, D. G. (2010). Higher hospital costs and lengths of stay associated with quinolone-resistant Salmonella enterica infections in Hong Kong. J. Public Health (Oxf.) 32, 165-172. doi: 10.1093/pubmed/fdp057

Brydon, L., Walker, C., Wawrzyniak, A. J., Chart, H., and Steptoe, A. (2009). Dispositional optimism and stress-induced changes in immunity and negative mood. Brain Behav. Immun. 23, 810-816.

Candiano, G., Bruschi, M., Musante, L., Santucci, L., Ghiggeri, G. M., Carnemolla B., et al. (2004). Blue silver: a very sensitive colloidal Coomassie G-250 staining for proteome analysis. Electrophoresis 25, 327-1333. doi: 10.1002/elps.200305844 
Cornish-Bowden, A. (1995). Fundamentals of Enzyme Kinetics, 3rd Edn. London: Portland Press.

Cosgrove, S. E., Sakoulas, G., Perencevich, E. N., Schwaber, M. J., Karchmer, A. W., and Carmeli, Y. (2003). Comparison of mortality associated with methicillinresistant and methicillin-susceptible Staphylococcus aureus bacteremia: a metaanalysis. Clin. Infect. Dis. 36, 53-59. doi: 10.1086/377611

Debnath, M., and Bisen, P. S. (2008). Jatropha curcas L., a multipurpose stress resistant plant with a potential for ethnomedicine and renewable energy. Curr. Pharm. Biotechnol. 9, 288-306. doi: 10.2174/138920108785161541

Dubois, M., Gilles, K. A., Hamilton, J. K., Rebers, P. A., and Smith, F. (1956). Colorimetric method for determination of sugars and related substances. Anal. Chem. 28, 350-354. doi: 10.1021/ac60111a017

Erlanger, B. F., Kolowsky, M., and Cohen, W. (1961). The preparation and properties of two new chromogenic substrates of trypsin. Arch. Biochem. Biophys. 95, 271278. doi: 10.1016/0003-9861(61)90145-X

Goel, G., Makkar, H. P., Francis, G., and Becker, K. (2007). Phorbol esters: structure, biological activity, and toxicity in animals. Int. J. Toxicol. 26, 279-288. doi: 10.1080/10915810701464641

González-Lamothe, R., Mitchell, G., Gattuso, M., Diarra, M. S., Malouin, F., and Bouarab, K. (2009). Plant antimicrobial agents and their effects on plant and human pathogens. Int. J. Mol. Sci. 10, 3400-3419. doi: 10.3390/ijms 10083400

Hancock, R. E. (2000). Cationic antimicrobial peptides: toward clinical applications. Expert Opin. Investig. Drugs 9, 1723-1729. doi: 10.1517/13543784.9.8.1723

Hughes, D. F., Devocelle, M., and Humphreys, H. (2012). Beyond conventional antibiotics for the future treatment of methicillin-resistant Staphylococcus aureus infections: two novel alternative. FEMS Immunol. Med. Microbiol. 65, 399-412. doi: 10.1111/j.1574-695X.2012.00954.x

Islam, M. A., Alam, M. M., Choudhury, M. E., Kobayashi, N., and Ahmed, M. U. (2008). Determination of minimum inhibitory concentration (MIC) of cloxacillin for selected isolates of methicillin-resistant Staphylococcus aureu (MRSA) with their antibiogram. Bangladesh J. Vet. Med. 6, 121-126.

Kim, J.-Y., Park, S.-C., Hwang, I., Cheong, H., Nah, J.-W., Hahm, K.-S., et al. (2009). Protease inhibitors from plants with antimicrobial activity. Int. J. Mol. Sci. 10, 2860-2872. doi: 10.3390/ijms10062860

Kim, M. H., Park, S. C., Kim, J. Y., Lee, S. Y., Lim, H. T., Cheong, H., et al. (2006). Purification and characterization of a heat-stable serine protease inhibitor from the tubers of new potato variety "Golden Valley". Biochem. Biophys. Res. Commun. 346, 681-686. doi: 10.1016/j.bbrc.2006.05.186

Klomklao, S., Benjakul, S., Kishimura, H., and Chaijan, M. (2011). Extraction, purification and properties of trypsin inhibitor from Thai mung bean (Vigna radiate (L.) R. Wilczek). Food Chem. 129, 1348-1354. doi: 10.1016/j.foodchem.2011.05.029

Kridric, M., Fabian, H., Brzin, J., Popovic, T., and Pain, R. H. (2002). Folding, stability and secondary structure of a new cysteine dimeric proteinase inhibitor. Biochem. Biophys. Res. Commun. 297, 962-967. doi: 10.1016/S0006291X(02)02328-8

Laemmli, U. K. (1970). Cleavage of structural proteins during the assembly of the bacteriophage T4. Nature 227, 680-685. doi: 10.1038/227680a 0

Lima, T. B., Silva, O. N., Migliolo, L., Souza-Filho, C. R., Gonçalves, E. G., Vasconcelos, I. M., etal. (2011). A Kunitz proteinase inhibitor from corms of Xanthosoma blandum with bactericidal activity. J. Nat. Prod. 74, 969-975. doi: 10.1021/np200312r

Macedo, M. L., de Sá, C. M., Freire, M. D., and Parra, J. R. (2004). A Kunitz-type inhibitor of coleopteran proteases, isolated from Adenanthera pavonina L. seeds and its effect on Callosobruchus maculatus. J. Agric. Food Chem. 52, 2533-2540. doi: $10.1021 / \mathrm{jf} 035389 \mathrm{z}$

Macedo, M. L., Diz Filho, E. B., Freire, M. G., Oliva, M. L., Sumikawa, J. T., Toyama, M. H., etal. (2011). A trypsin inhibitor from Sapindus saponaria L. seeds: purification, characterization, and activity towards pest insect digestive enzyme. Protein J. 30, 9-19. doi: 10.1007/s10930-010-9296-7

Machado, R. J., Monteiro, N. K., Migliolo, L., Silva, O. N., Pinto, M. F., Oliveira, A. S., et al. (2013). Characterization and pharmacological properties of a novel multifunctional Kunitz inhibitor from Erythrina velutina seeds. PLoS ONE 8:e63571. doi: 10.1371/journal.pone.0063571

Maciel, F. M., Laberty, M. A., Oliveira, N. D., Felix, S. P., Soares, A. M., Verícimo, M. A., et al. (2009). A new $2 S$ albumin from Jatropha curcas L. seeds and assessment of its allergenic properties. Peptides 30, 2103-2107. doi: 10.1016/j.peptides.2009.08.008
Mandal, S., Kundu, P., Roy, B., and Mandal, R. K. (2002). Precursor of the inactive $2 S$ seed storage protein from the Indian mustard Brassica juncea is a novel trypsin inhibitor. Characterization, post-translational processing studies, and transgenic expression to develop insect-resistant plants. J. Biol. Chem. 277, 37161-37168. doi: $10.1074 /$ jbc.M205280200

Mulvey, M. R., and Simor, A. E. (2009). Antimicrobial resistance in hospitals: how concerned should we be? CMAJ 180, 408-415. doi: 10.1503/cmaj.080239

Ngo, L. T., Okogun, J. I., and Folk, W. R. (2013). 21st century natural product research and drug development and traditional medicines. Nat. Prod. Rep. 30, 584-592. doi: 10.1039/c3np20120a

Nyembo, K., Kikakedimau, N., Mutambel, H., Mbaya, N., Ekalakala, T., and Bulubulu, O. (2012). In vitro antibacterial activity and phytochemical screening of crude extracts from Jatropha curcas Linn. Eur. J. Med. Plants 2, 242-251.

Rachana, S., Tarun, A., Rinki, R., Neha, A., and Meghna, R. (2012). Comparative analysis of antibacterial activity of Jatropha curcas fruit parts. J. Pharm. Biomed. Sci. 15, 1-4.

Ramsamy, Y., Muckart, D. J. J., and Han, K. S. S. (2013). Microbiological surveillance and antimicrobial stewardship minimise the need for ultrabroad-spectrum combination therapy for treatment of nosocomial infections in a trauma intensive care unit: an audit of an evidence-based empiric antimicrobial policy. S. Afr. Med. J. 103, 371-376. doi: 10.7196/SAMJ.6459.

Rashid, U., Anwar, F., Jamil, A., and Bhatti, H. N. (2010). Jatropha curcas seed oil as a viable source for biodiesel. Pak. J. Bot. 42, 575-582.

Sabandar, C. W., Ahmat, N., Jaafar, F. M., and Sahidin, I. (2013). Medicinal property, phytochemistry and pharmacology of several Jatropha species (Euphorbiaceae) a review. Phytochemistry 85, 7-29. doi: 10.1016/j.phytochem.2012.10.009

Saetae, D., and Suntornsuk, W. (2011). Toxic compound, anti-nutritional factors and functional properties of protein isolated from detoxified Jatropha curcas seed cake. Int. J. Mol. Sci. 12, 66-77. doi: 10.3390/ijms12010066

Savoia, D. (2012). Plant-derived antimicrobial compounds: alternatives to antibiotics. Future Microbiol. 7, 979-990. doi: 10.2217/fmb.12.68

Speranskaya, A. S., Krinitsina, A. A., Revina, T. A., Gerasimova, N. G., Keruchen'ko, Y. S., Shevelev, A. B., et al. (2006). Heterologous expression, purification, and properties of a potato protein inhibitor of serine proteinases. Biochemistry 71 1176-1182. doi: 10.1134/S0006297906110022

Sriprang, S., Sriprang, N., Sumpradit, T., and Shimbhu, D. (2010). Antibacterial activities of crude extracts from physic nut (Jatropha curcas) seed residues. Sci. Asia 36, 346-348. doi: 10.2306/scienceasia1513-1874.2010.36.346

Srividhya, K. P., Tamizharasan, T., Jayaraj, S., and Muralledharan, C. (2010). Characterization and gasification using Jatropha curcas seed cake. J. Biofuels 1, 30-36. doi: $10.5958 / j .0976-3015.1 .1 .005$

Sundari, J., and Selvaraj, R. (2011). Antibacterial and antifungal activity of seed extract from Jatropha curcas Linn. Int. J. Curr. Res. 3, 84-87.

Terras, F. R. G., Torrenkens, S., Van Leuven, F., Osborn, R. W., Vanderleyden, J., Cammue, B. P. A., et al. (1993). A new family of basic cysteine-rich plant antifungal proteins from Brassicaceae species. FEBS J. 316, 233-240.

Tripathi, V. R., Kumar, S., and Garg, S. K. (2011). A study on trypsin, Aspergillus flavus and Bacillus sp. protease inhibitory activity in Cassia tora (L.) syn Senna tora (L.) Roxb. seed extract. BMC Complement. Altern. Med. 11:56. doi: 10.1186/14726882-11-56

van Hal, S. J., Jensen, S. O., Vaska, V. L., Espedido, B. A., Paterson, D. L., and Gosbell, I. B. (2012). Predictors of mortality in Staphylococcus aureus bacteremia. Clin. Microbiol. Rev. 25, 362-386. doi: 10.1128/CMR.05022-11

Vasconcelos, I. M., Trentin, A., Guimarães, J. A., and Carlini, C. R. (1994). Purification and physicochemical characterization of soyatoxin, a novel toxic protein isolated from soybeans (Glycine max). Arch. Biochem. Biophys. 312, 357-366. doi: 10.1006/abbi. 1994.1320

Volpicella, M., Leoni, C., Costanza, A., De Leo, F., Gallerani, R., and Ceci, L. R. (2011). Cystatins, serpins and other families of protease inhibitors in plants. Curr. Protein Pept. Sci. 12, 386-398. doi: 10.2174/138920311796391098

Wang, S., and Rao, P. (2010). A leguminous trypsin-chymotrypsin inhibitor Limenin with antifungal activity from Phaseolus limensis. Eur. Food Res. Technol. 231, 331-338. doi: 10.1007/s00217-010-1285-8

Zacharius, R. M., Zell, T. E., Morrison, J. H., and Woodlock, J. J. (1969). Glycoprotein staining following electrophoresis on acrylamide gels. Anal. Biochem. 30, 148 152. doi: 10.1016/0003-2697(69)90383-2

Zhao, Q., Wang, W., Wang, Y., Xu, Y., and Chen, F. (2012). The effect of curcin from Jatropha curcas on apoptosis of mouse sarcoma-180 cells. Fitoterapia 83, 849-52. doi: 10.1016/j.fitote.2012.03.005 
Conflict of Interest Statement: The authors declare that the research was conducted in the absence of any commercial or financial relationships that could be construed as a potential conflict of interest.

Received: 10 October 2013; accepted: 06 January 2014; published online: 30 January 2014.

Citation: Costa HPS, Oliveira JTA, Sousa DOB, Morais JKS, Moreno FB, MonteiroMoreira ACO, Viegas RA and Vasconcelos IM (2014) JcTI-I: a novel trypsin inhibitor from Jatropha curcas seed cake with potential for bacterial infection treatment. Front. Microbiol. 5:5. doi: 10.3389/fmicb.2014.00005
This article was submitted to Antimicrobials, Resistance and Chemotherapy, a section of the journal Frontiers in Microbiology.

Copyright (c) 2014 Costa, Oliveira, Sousa, Morais, Moreno, Monteiro-Moreira, Viegas and Vasconcelos. This is an open-access article distributed under the terms of the Creative Commons Attribution License (CC BY). The use, distribution or reproduction in other forums is permitted, provided the original author(s) or licensor are credited and that the original publication in this journal is cited, in accordance with accepted academic practice. No use, distribution or reproduction is permitted which does not comply with these terms. 